\title{
Estimation of microalgae resource potential for bio-oil production and sustainable rural development in the climatic conditions of Russia (the Republic of Dagestan)
}

\author{
Nadezhda I. Chernova ${ }^{1,2}$, Sofya V. Kiseleva ${ }^{1,2}$, Mikhail S. Vlaskin ${ }^{2}$ and Yulia Yu. Rafikova, ${ }^{1, *}$ \\ ${ }^{1}$ Lomonosov Moscow State University, Leninskie Gory, 1, Moscow, Russia \\ ${ }^{2}$ Joint Institute for High Temperatures of Russian Academy of Science, Moscow, Russia
}

\begin{abstract}
The work is devoted to the estimation of microalgae resource potential for bio-oil production. We propose a method of climate and infrastructural factors spatial analysis for estimations of resource and the possibility of bio-oil production facilities construction in the study region. The resource potential depends on the area of the territory that can be used to produce biomass as feedstock for biofuel production, and equal to the amount of microalgae biomass that can be obtained on this territory. For the case study we selected the territory of the Republic of Dagestan (Russia) and microalgae Arthrospira platensis and Dunaliella salina. As an infrastructural factors, which may reduce the cost of bio-oil production we considered the following sources of cheap material resources and energy: seawater (as a source of macro- and microelements), geothermal water (as low-temperature heat source), $\mathrm{CO}_{2}$ emissions of cement plants and combined heat and power plants (as carbon source and to reduce $\mathrm{CO}_{2}$ emission). The analyses of these factors using the technology of geoinformation systems allowed to find the most suitable territories for microalgae plant allocation and therefore estimate resource potential for biooil production with maximum profit.
\end{abstract}

\section{Introduction}

Microalgae biofuel technologies attract great attention of researchers due to high productivity of microalgae in comparison with traditional biofuel cultures. Saline and sewage, as well as areas unsuitable for crop production, can be used for their cultivation. The lability of the composition characteristic of microalgae makes it possible to obtain biomass with specified properties. In particular, it is possible to obtain biomass of microalgae with a high content of carbon, i.e. with the highest content of lipids or carbohydrates and lower content of proteins. In this case, the yield of biofuel from microalgae increases. Depending on biochemical composition of microalgae and necessary type of biofuel the microalgae are processed by means of different technologies: hydrothermal liquefaction (HTL), gasification or pyrolysis. In addition to the fuel production, the growing of microalgae can serve as a mean for

\footnotetext{
${ }^{*}$ Corresponding author: ju.rafikova@gmail.com
} 
removing carbon dioxide from the atmosphere or maintaining zero carbon balance. Besides biofuel the biomass of microalgae can be used as a source for a number of valuable coproducts, for example, nutraceuticals that provide high added value.

Microalgae are cultivated in a closed way in photobioreactors or with a cheap open method in outdoor ponds or in a greenhouse complexes. Earlier in our work [1] we considered technologies for microalgae use as new unconventional feedstock to produce biofuels and co-products and showed that only the southern regions of the Russian Federation (Stavropol and Krasnodar Territories, Rostov and Astrakhan Regions, Republic of Dagestan) are suitable for microalgae production due to their climatic conditions. It was assumed that algae in this region could be grown in outdoor ponds in the warm season. So the purpose of this article is evaluation of microalgae resource potential as a feedstock for biofuel and coproducts on the case-study territory. As the resource potential we proposed amount of microalgae biomass that can be obtained on the territory and therefore it depends on the territory area that can be used to produce biomass as feedstock for biofuel production.

Selecting the area that can be occupied by the cultivation of microalgae, we proceeded from the necessity to reduce cost of the entire production cycle and therefore to increase microalgae biofuel competitiveness. Such cost reducing is determined by a whole number of territorial conditions or factors. Therefore, research and analysis of various factors, including physical, geographical and infrastructural, is of great importance. Such studies require the application of biology, biotechnology and geoinformation systems (GIS) methods.

We selected the territory of the Republic of Dagestan (Russia) for a case study on searching optimal locations for the microalgae plants and evaluating of resource potential of microalgae as a feedstock for biofuel. Climatic and infrastructural factors which value on where microalgae biomass cultivation is not only possible, but this cultivation can be carried out with minimal costs, were sequentially examined for the selected territory. Zoning of the territory and allocation of areas that provide the maximum potential for the production of microalgae using GIS technologies, as a result, determine the area of the most optimal territories. Further on the basis of literature data, as well as own experimental results, the resource potential was determined as the annual yields of microalgae in these areas and the amount of biofuel production from them.

\section{Physical-geographical factors influence on the resource potential of biofuel production from microalgae}

The size of areas available for cultivation of microalgae is determined first of all by physicalgeographical factors (Table 1).

1. Considering the presence of the required climatic factors in the territory of Dagestan that is located in the north-eastern part of the Caucasus with access to the coast of the Caspian Sea. The territory of the Republic of Dagestan is small $\left(50300 \mathrm{~km}^{2}\right)$, and the length of territory does not exceed $4^{\circ}$ from north to south and from west to east. Therefore, the arrival of solar irradiance is almost the same throughout the territory, and the distribution of air temperatures is determined primarily by the high zoning and the influence of the Caspian Sea. We examined Arthrospira/Spirulina platensis and Dunaliella salina as microalgae for which all the estimations were carried out. These two types of microalgae are cultivated on an industrial scale with a cheap open method both for use as the nutraceuticals to fodder and food, and for the production of biofuels [1-4]. The required temperature and irradiance for cultivation are the same as those indicated in Table 1.

Table 2 shows that the required for cultivation climatic conditions are available in the territory of Dagestan during the warm season from May to September without additional supply of thermal and luminous energy. 
Table 1. Physical-geographical factors of microalgae biomass production as feedstock for biofuel production.

\begin{tabular}{|c|c|c|c|}
\hline № & $\begin{array}{c}\text { Physical-geographical } \\
\text { factor }\end{array}$ & Type of factor & $\begin{array}{l}\text { The value of the factor / } \\
\text { qualitative characteristic }\end{array}$ \\
\hline \multirow{3}{*}{1} & \multirow{3}{*}{ Climate factors } & $\begin{array}{l}\text { Insolation incident on a } \\
\text { horizontal surface }\end{array}$ & $\begin{array}{l}\text { At least } 4 \mathrm{kWh} / \mathrm{m}^{2} / \text { day (or } 14 \\
\mathrm{MJ} / \mathrm{m}^{2} \text { ) }\end{array}$ \\
\hline & & $\begin{array}{l}\text { Duration of the light period } \\
\text { during the day }\end{array}$ & $\begin{array}{c}\text { At least 6:18 (ratio of dark and } \\
\text { light phase) }\end{array}$ \\
\hline & & Air temperature & $\begin{array}{c}\text { The average daily temperature } \\
\text { is not lower than }+15^{\circ} \mathrm{C}\end{array}$ \\
\hline 2 & Geomorphological factors & Slope of the surface & Not more than $5 \%$ \\
\hline \multirow{3}{*}{3} & \multirow{3}{*}{$\begin{array}{l}\text { Natural resources for the } \\
\text { production of microalgae }\end{array}$} & $\begin{array}{l}\text { Source of thermal waters with } \\
\text { thermal water temperature not } \\
\text { below } 35-40^{\circ} \mathrm{C}\end{array}$ & Availability is desirable \\
\hline & & Source of fresh water & Necessary for growing algae \\
\hline & & Source of sea water & Availability is desirable \\
\hline
\end{tabular}

Table 2. Climatic characteristics* of the Dagestan territory (long-term meteorological data for the period 2005-2018 for the city of Makhachkala) [5].

\begin{tabular}{|c|c|c|c|c|}
\hline & $\begin{array}{l}\text { Average air } \\
\text { temperature } \\
\text { at the height } \\
\text { of } 2 \mathrm{~m},{ }^{\circ} \mathrm{C}\end{array}$ & $\begin{array}{l}\text { Daylight hours } \\
\text { (average per } \\
\text { month) }\end{array}$ & $\begin{array}{c}\text { Ratio of light } \\
\text { and dark phase } \\
\text { (hours, average } \\
\text { per month) }\end{array}$ & $\begin{array}{c}\text { Insolation incident } \\
\text { on a horizontal } \\
\text { surface (average } \\
\text { daily sum, } \mathbf{M J} / \mathbf{m}^{2} \text { ) }\end{array}$ \\
\hline January & +0.4 & 73 & $7.40: 16.20$ & 4.64 \\
\hline February & +1.2 & 72 & $9.41: 14.19$ & 6.7 \\
\hline March & +5.4 & 108 & 11.49:12.11 & 10.36 \\
\hline April & +10.5 & 175 & 14.12:9.48 & 16.38 \\
\hline May & +17.1 & 244 & 16.18:7.42 & 21.87 \\
\hline June & +22.6 & 276 & $17.32: 6.28$ & 23.95 \\
\hline July & +25.2 & 286 & 16.58:7.02 & 23.17 \\
\hline August & +25.6 & 273 & $15.04: 8.56$ & 20.28 \\
\hline September & +21.0 & 197 & 12.46:11.14 & 14.82 \\
\hline October & +14.3 & 153 & $10.29: 23.31$ & 9.97 \\
\hline November & +7.8 & 85 & 08.18:15.42 & 5.4 \\
\hline December & +4.0 & 66 & $07.30: 16.30$ & 4.0 \\
\hline
\end{tabular}

* The yellow colour indicates those values. which correspond to the requirements for cultivation of microalgae in open ponds without additional energy consumption for heating and lighting. The period of open cultivation of microalgae is marked with a red color.

In addition to the climatic factors we considered other physical and geographical characteristics of Dagestan territory: the slope of the surface. the availability of geothermal sources and sources of sea water.

2. In the region under investigation a number of areas are characterized by strongly dissected relief and a significant surface slope: foothill. mountainous and highland Dagestan. We have adopted only territories with a slope of less than $5 \%$ as suitable for large-scale cultivation of microalgae. With the use of remote sensing data we selected the territories of lowlands. which are situated at the northern and eastern parts of the region.

3. In terms of sea water sources availability. the most suitable areas for microalgae 
cultivation are situated at the coast of the Caspian Sea. Comparison of macro- and microelements compositions in microalgae nutrient media (Zarrouk's medium) and water of the Caspian Sea $[6,7]$ showed. that the use of the Caspian Sea water in the process of nutrient medium preparation for Arthrospira/Spirulina compensates adding to culture medium potassium and magnesium sulphates. calcium and sodium chlorides [8]. since all of these elements are presented in seawater. So it will be enough to add only nitrogen. phosphoric and carbon nutrition to water. For Dunaliella. it is necessary to introduce sodium chloride and magnesium sulphate in accordance with the culture medium of Semenenko-Abdullaev. in which Dunaliella is cultivated [9]. The contents of essential trace elements in sea water correspond to the required amounts for microalgae cultivation media.

Geothermal springs as cheap thermal energy resources for microalgae cultivating systems can increase the profitability of projects by heating the pools at night and at cold period and therefore increasing the period of microalgae growth during the year. The territory of Dagestan is rich in geothermal fields. Most of Dagestan is in the zone of thermal water sources with a temperature of $50-100^{\circ} \mathrm{C}$. The districts of Makhachkala and Izberbash. where the thermal waters extracted from the depths of 1-1.5 km are used for household heating and hot water supply. can be considered as promising territories for the microalgae cultivation.

\section{Infrastructural factors influence on the resource potential of biofuel production from microalgae}

Infrastructural factors that were taken into account during the selection of the most suitable regions in the territory of the Republic of Dagestan are the following:

1. The road network allows significantly reduce of the total energy consumption for the production of biomass microalgae and biofuel due to the location of cultivating systems near the sources of feedstock. water and consumers of basic products and co-products of microalgae production. for example. near the enterprises producing mixed fodder. Colocalization of production processes and sources of feedstock provide near zero energy costs for transporting of necessary chemicals as well as target and co-products.

2. Sources of cheap low-potential heat for cultivation of microalgae such as geothermal fields and thermal power plants.

3. Stationary sources of $\mathrm{CO}_{2}$ : thermal power plants. cement plants. glass plants and fertilizer plants. Emissions of $\mathrm{CO}_{2}$ from the cement industry of Dagestan and Makhachkala CHP are around 2555000 tones/year [10]. Assimilation of such amount of $\mathrm{CO}_{2}$ by microalgae with an average biomass productivity of $20 \mathrm{~g} / \mathrm{m}^{2} /$ day will produce 1867000 tons of microalgae. Makhachkala CHP also emits sulfur dioxide - 4 tons/year. nitrogen oxides 21 tons/year (in terms of $\mathrm{NO}_{2}$ ). Nitrogen and sulfur are biogenic elements and are necessary for the microalgae growth. therefore $\mathrm{NO}_{\mathrm{x}}$ and $\mathrm{SO}_{\mathrm{x}}$ emissions after their purification can also be assimilated by microalgae.

4. Consumers of the target products: for biofuels - boiler houses. agricultural transport. greenhouse complexes; for co-products - poultry and livestock. According to our previous work [11]. the current poultry stock in Dagestan requires about 300 tons of microalgae biomass/year (in case of addition of this biomass to usual feed in amount of 1\%). In the long term. it is possible to envisage the target production of vitamin supplements (carotenoids. vitamins $\mathrm{A}$ and $\mathrm{B}$ ) from microalgae. and the remaining bulk of biomass can be used for transformation into biofuel.

5. Territories on which the large cultivating systems are prohibited due to government restrictions. Such areas included specially protected natural areas. industrial areas. recreation areas. vineyards and gardens. residential areas. Based on the above-mentioned physicalgeographical and infrastructural factors. a promising area of the Caspian coastal lowland. which includes the Makhachkala and Kayakent administrative regions. have been chosen 
(Figure 1). The placement of systems for the cultivation and processing of microalgae biomass in this area will be optimum due to the complex of factors analyzed in this case study. which result is performed with the map of territory suitability on Figure 1.

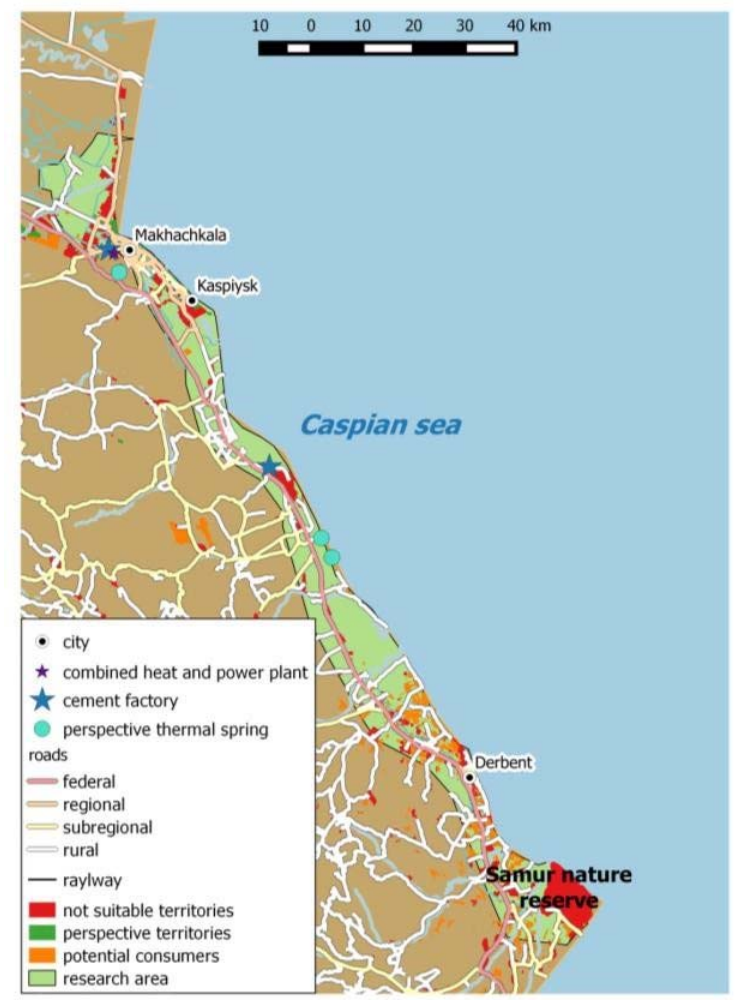

Fig. 1. Territories most suitable for cultivation of microalgae in the territory of the Republic of Dagestan. The following infrastructure factors are indicated: a) roads; b) thermal springs. with a temperature of more than $40^{\circ} \mathrm{C}$; c) land use restrictions; d) potential consumers (poultry and livestock farms); d) large sources of $\mathrm{CO}_{2}$ emissions (CHP. cement factories).

With the use of Quantum GIS program instruments we studied the spatial interposition of all the above factors. identified and highlighted with red color the territories. which for some reason are not suitable for placing microalgae plants. These are the territories of the Samur nature reserve (in the south of the map) and those that have significant land use restrictions. The area of suitable lands for cultivation of microalgae was estimated as $1500 \mathrm{~km}^{2}$. Of course. we cannot say that the whole these area can be occupied for the production of microalgae. Therefore. we considered only the territories located near the sources of low potential heat. sea water and consumers. and also characterized by such types of land use that do not interfere with the condition of placing large-scale objects on them (wastelands. saline soils. wastelands. etc.). We assumed that $5 \%$ of suitable territory could be used for algae plantations. Based on data on the productivity of Dunaliella salina in the near climatic conditions of Andalusia [3]. as well as on the base of own experience in the cultivation of Spirulina platensis [12]. the potential amount of microalgae biomass that could be produced in this area with an average daily productivity of $20 \mathrm{~g} / \mathrm{m}^{2}$. vegetation period of 5 months is equals to 225000 tons. The processing of microalgae biomass by technology of hydrothermal liquefaction at temperatures of $330^{\circ} \mathrm{C}$ leads to $40 \%$ yield of bio-oil in accordance with [13]. Therefore. the potential of bio-oil production from microalgae in the territory of Dagestan is 90000 tones/year. 


\section{Conclusions}

Spatial analysis of the influence of climatic and infrastructural factors on the resource potential of the production of microalgae and biofuel from them was carried out.

On the case study region (Republic of Dagestan) we have chosen territories suitable for cultivation of microalgae which are provided with transport accessibility. electric grids. sources of anthropogenic $\mathrm{CO}_{2}$ (thermal power plants. cement plants). sea water. mineralized groundwater. sources of low-potential heat (thermal waters and thermal power plants). Potential consumers of biofuel and co-products (poultry factories. livestock complexes) as well as government restrictions were also taken into account. Territories that are optimal for microalgae cultivation are located on the coast of the Caspian Sea in Makhachkala and Kayakent regions and their area is $1500 \mathrm{~km}^{2}$. Using $5 \%$ of this area for the microalgae cultivation. it is possible to obtain 225000 tons of biomass and 90000 tons of bio-oil by means of HTL-method over a warm period of the year.

The use of GIS-technologies provided quick analysis of many heterogeneous factors for a vast area. At the same time. the shortage of this method is uneven distribution. insufficient accuracy and lack of vector data for case study territory.

The authors are grateful to the Russian Science Foundation (project №17-19-01617) for the financial support of the study. The map is constructed by Yu.Yu. Rafikova.

\section{References}

1. N.I. Chernova. S.V. Kiseleva. M.S. Vlaskin. Y.Y. Rafikova. MATEC Web of Conf. 112, 1-6 (2017)

2. A. Milbrandt. E. Jarvis. (2010). http://www.nrel.gov/docs/fy10osti/48380.pdf

3. M. García-González. J. Moreno. J.P. Cañavate. V. Anguis. A. Prieto. C. Manzano. F.J.. F. and M.G. Guerrero. J. Appl. Phyc. 15, 177-184 (2003)

4. N.I. Chernova. S.V. Kiseleva. M.S. Vlaskin. Int. J. of En. Cl. Env. 18, 132-145 (2017)

5. https://power.larc.nasa.gov

6. V.S. Brezgunov. V.I. Ferronskiy. Vodnyye resursy. 31, 1, 73-77 (2004)

7. A.A. Zenin. N.V. Belousova. Gidrokhimicheskiy slovar'. (Gidrometeoizdat. 1988)

8. C. Zarrouk. Contribution a l'etude d' une cyanophycee. Influence de diverse facteursphysiques et chimiques sur la croissance et la photosynthese de Spirulina maxima (Setch et Gardner) Geitler. (France: University of Paris. 1966)

9. Katalog cultur microvodoroslei v collektsiyakh SSSR (IPPRAS Publ.. Moscow. 1991)

10. B.E. Yudovich. A.M. Dmitriev. Yu.A. Lyamin. Cement industry and ecology, 3, 1119 (1998)

11. T.M Okolelova, I.P Baykovskaya, A.A. Solov'yev, N.I. Chernova, etc. RF Patent №2034499 (1995)

12. N.I. Chernova. S.V. Kiseleva. T.P. Korobkova. S.I. Zaytsev. Altern. Energ. Ecol. 9. 6874 (2008)

13. M.S. Vlaskin. N.I. Chernova. S.V. Kiseleva. L.A. Dombrovsky. Proc. 16th Intern. Heat Transf. Conference. IHTC-16. IHTC16-22357 (2018) 